\title{
Patient safety in the prevention and care of skin lesions in newborns: integrative review
}

\author{
Segurança do paciente na prevenção e cuidado às lesões de pele em recém-nascidos: revisão integrativa
}

Seguridad del paciente en la prevención y cuidado con las lesiones de piel en recién nacidos: revisión integradora

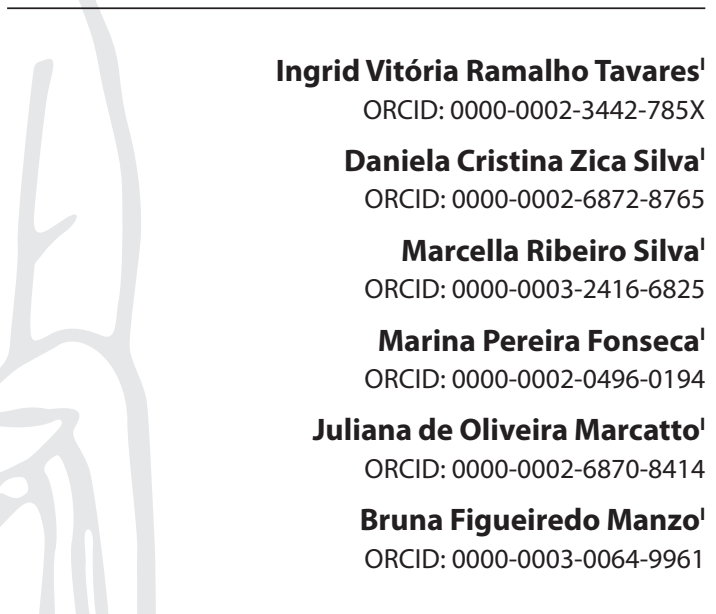

'Universidade Federal de Minas Gerais. Belo Horizonte, Minas Gerais, Brazil.

How to cite this article: Tavares IVR, Silva DCZ, Silva MR, Fonseca MP, Marcatto JO, Manzo BF. Patient safety in the prevention and care of skin lesions in newborns: integrative review. Rev Bras Enferm. 2020;73(Suppl4):e20190352. doi: http://dx.doi.org/10.1590/0034-7167-2019-0352

\section{Corresponding author: Bruna Figueiredo Manzo E-mail: brunaamancio@yahoo.com.br}

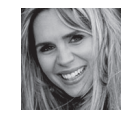

EDITOR IN CHIEF: Antonio José de Almeida Filho ASSOCIATE EDITOR: Fátima Helena Espírito Santo

Submission: 05-04-2019

Approval: $12-05-2019$

\section{ABSTRACT}

Objective: to describe the main evidence available in the literature on safe practices in the prevention and care of skin lesions in newborns admitted to Neonatal Intensive Care Units. Methods: integrative literature review in the PubMed, BDENF, LILACS, MEDLINE, SCiELO and Cochrane Library databases between 2013 and 2018. We included primary articles on: lesion prevention and skin care in newborns in Portuguese, English or Spanish and excluded editorials, thesis, dissertations and duplicate articles. For the evidence level, we used the Melnyk and Fineout-Overholt classification, which classifies studies between weak to strong evidence. Results: a total of 10 articles with moderate to weak evidence on thermoregulation, bathing, lesion prevention, use of patches and skin antisepsis. Final considerations: there was a shortage of publications with high evidence, and it is necessary to invest in research that seeks to support safer skin care practices.

Descriptors: Newborn; Skin; Nursing; Nursing Care; Patient Safety.

\section{RESUMO}

Objetivo: descrever as principais evidências disponíveis na literatura sobre as práticas seguras na prevenção e cuidado com as lesões cutâneas em recém-nascidos internados em Unidades de Terapia Intensiva Neonatal (UTIN). Método: revisão integrativa da literatura nas bases de dados PubMed, BDENF, LILACS, MEDLINE, SciELO e Cochrane Library, entre 2013 e 2018. Foram incluídos artigos primários sobre: prevenção de lesão e cuidados com a pele em recém-nascidos, em português, inglês ou espanhol e excluídos editoriais, teses, dissertações e artigos duplicados. Para o nível de evidência, foi utilizado o modelo de Melnyk e Fineout-Overholt, que classifica os estudos entre evidência fraca a forte. Resultados: inclusão de dez artigos com evidência moderada a fraca sobre a termorregulação, o banho, a prevenção de lesões, o uso de adesivos e antissepsia da pele. Considerações finais: foi observada escassez de publicações com evidência alta, sendo necessário investir em pesquisas que busquem subsidiar práticas mais seguras de cuidados com a pele.

Descritores: Recém-Nascido; Pele; Enfermagem; Cuidados de Enfermagem; Segurança do Paciente.

\section{RESUMEN}

Objetivo: describir la principal evidencia disponible en la literatura sobre prácticas seguras en la prevención y atención de lesiones cutáneas en recién nacidos ingresados en Unidades de Cuidados Intensivos Neonatales. Métodos: revisión integradora de la literatura en las bases de datos PubMed, BDENF, LILACS, MEDLINE, SciELO y Cochrane Library entre 2013 y 2018. Incluimos artículos primarios sobre: prevención de lesiones y cuidado de la piel en recién nacidos, en portugués, inglés o español y excluimos editoriales, tesis, disertaciones y artículos duplicados. Para el nivel de evidencia, utilizamos el modelo de Melnyk y Fineout-Overholt, que clasifica los estudios entre evidencia débil a fuerte. Resultados: inclusión de diez artículos con evidencia moderada a débil sobre termorregulación, baño, prevención de lesiones, uso de parches y antisepsia de la piel. Consideraciones finales: hubo una escasez de publicaciones con evidencia fuerte, y es necesario invertir en investigaciones que busquen apoyar prácticas más seguras para el cuidado de la piel.

Descriptores: Recién Nacido; Piel; Enfermería; Cuidados de Enfermería; Seguridad del Paciente. 


\section{INTRODUCTION}

The newborn's (NB) epidermal barrier begins to form in the womb and its histological development is complete at 34 weeks of gestation. At birth, the stratum corneum of newborn children resembles that of adults, while in the preterm newborn (PTN) there are few layers of stratum corneum and the cells are thinner ${ }^{(1)}$.

Both full-term and preterm infants offer greater predisposition to skin lesions due to increased permeability, which causes greater water loss, electrolyte and temperature disturbances, and greater exposure to environmental irritants and infectious agents ${ }^{(1)}$. Linked to these factors, hospitalization in Neonatal Intensive Care Units (NICU) is a highly complex care scenario, which involves high risk to the patient due to the physiological and hemodynamic instability of the newborn and the characteristics and diversity of procedures performed, which requires continuous patient monitoring to avoid breach of care safety ${ }^{(2-3)}$.

During hospitalization, careful temperature adjustment and humidity control of the environment are crucial in keeping the integrity of the skin. The daily routine of care in the NICU subjects the newborn to risk for skin integrity rupture many times, from simple interventions such as manipulation and positioning, bathing, fixation, removal of tapes and devices, to performing invasive procedures such as venous and arterial punctures ${ }^{(4)}$.

Based on the above considerations, this study suggests the need to rethink patient safety in the NICU, with a view to reducing health care-related damage and adverse events and an emphasis on ensuring skin integrity. Lesion prevention is one of the international goals of the National Patient Safety Program ${ }^{(5)}$ created in $^{2}$ 2013, which reinforces the importance of investigating this theme.

With the objective of recommending actions for a safe practice of newborn's lesion prevention, the participation of the entire multidisciplinary team is central, especially the nursing team, which stays with the infant throughout the hospitalization period. Considering the importance of these actions for safe care for newborns, the professionals who perform them need to be empowered with scientific evidence knowledge so that they can be transferred to newborn care. Thus, the following question was elaborated: What is the evidence available in the literature about safe practices in the prevention and care of skin lesions in newborns?

Given the data presented, this study is justified by the contribution to restructure and organize the work process of multiprofessional teams regarding the adoption of newborn's safe skin care. The findings may also contribute to the creation of protocols that guide the clinical practice in skin care of the newborn.

\section{OBJECTIVE}

To describe the main evidence available in the literature on safe practices in the prevention and care of skin lesions in newborns admitted to Neonatal Intensive Care Units.

\section{METHODS}

Integrative review of the literature built from the following stages: development of the guiding question; search for primary studies in databases; data extraction from studies; evaluation of selected studies; analysis and synthesis of results and presentation of the review ${ }^{(6)}$. This research strategy aims to synthesize the findings of research found in the literature, seeking evidence for decision making, and present gaps in scientific knowledge that still need to be explored ${ }^{(7)}$.

The guiding question was inspired by the PICO strategy (Patient/population/disease; Intervention or issue of interest; Comparison, Intervention or issue of interest; Outcome). The population was defined as "NICU infants", Intervention as "Prevention and Skin Care Strategies", there was no Comparison, and Result as "Safety in Newborn Skin Integrity". Thus, the research question was presented as: "What evidence is available in the literature about safe practices in the prevention and care of skin lesions in newborns?"

The selected databases were US National Library of Medicine (PubMed), Nursing Database (BDENF), Latin American and Caribbean Health Science Literature (LILACS), Medical Literature Analysis and Retrieval System Online (MEDLINE), Scientific Electronic Library Online (SciELO) and the Cochrane Library. For the PubMed, MEDLINE and Cochrane Library database, the following Medical Subject Headings (MeSH Database) descriptors were used: newborn, skin, nursing, nursing care and patient safety, used with the help of Boolean term AND to search these databases (newborn AND skin AND nursing AND nursing care AND patient safety). For the BDENF, LILACS and SciELO database, the Health Sciences Descriptors (DeCS) were used: newborn (recém-nascido), skin (pele), nursing (enfermagem), nursing care (cuidados de enfermagem) and patient safety (segurança do paciente). To perform the search, these descriptors were arranged with the help of Boolean AND (newborn AND skin AND nursing AND nursing care AND patient safety).

Inclusion criteria for study pre-selection were: English, Portuguese or Spanish languages; and publications between January 2013 (the year the patient safety program was instituted) and December 2018. The texts of the dissertation, thesis, editorials and other articles that were not characterized as journal articles were excluded. Duplicate articles that did not meet the objective of this review and that were not available in full were also excluded.

The selection of articles was performed through careful reading of titles and abstracts, in order to verify whether the articles fit the final selection, meeting the above criteria. For the final selection, articles that presented the main evidence on safe practices for prevention and care of skin lesions in newborns were chosen.

For data collection and analysis, a too ${ }^{(8-9)}$ was used with a list of questions that measured the level of relevance and critical analysis of the results in order to select their exclusion and inclusion. This stage was performed by two independent researchers. When consensus was not possible, the evaluation of a third researcher was used.

For the level of evidence, the model suggested by Melnyk and Fineout-Overholt ${ }^{(10)}$ was used, which classifies the studies into seven levels: 1- evidence from systematic review or metaanalysis of randomized controlled trials or review-based clinical guidelines from systematic randomized controlled clinical trials; 2 - evidence from at least one well-designed randomized 
controlled clinical trial; 3 - evidence obtained from well-designed non-randomized clinical trials; 4 - evidence from well-designed cohort and case-control studies; 5 - evidence from systematic review of descriptive and qualitative studies; 6 - evidence derived from a single descriptive or qualitative study; 7 - Evidence from the opinion of authorities and/or expert committee report. According to this classification, levels 1 and 2 are considered strong, 3 and 4 moderate and 5-7 weak evidence.

During the process of identification, selection and inclusion of primary studies, the articles went through three stages. In the first stage, duplicate articles were removed and from the total of 80 articles, 11 were excluded. In the second stage, after reading the titles and abstracts of the remaining 69 articles, 49 articles were excluded because they did not include the theme under study. Thus, 20 articles were selected. In the third stage, the full reading of these 20 articles was performed, and a critical analysis based on the tool ${ }^{(8-9)}$ mentioned above. Nine articles were removed for not meeting the inclusion criteria and one for being unavailable in full. The final sample consisted of ten articles. Figure 1 illustrates the process of selecting articles included in this integrative review.

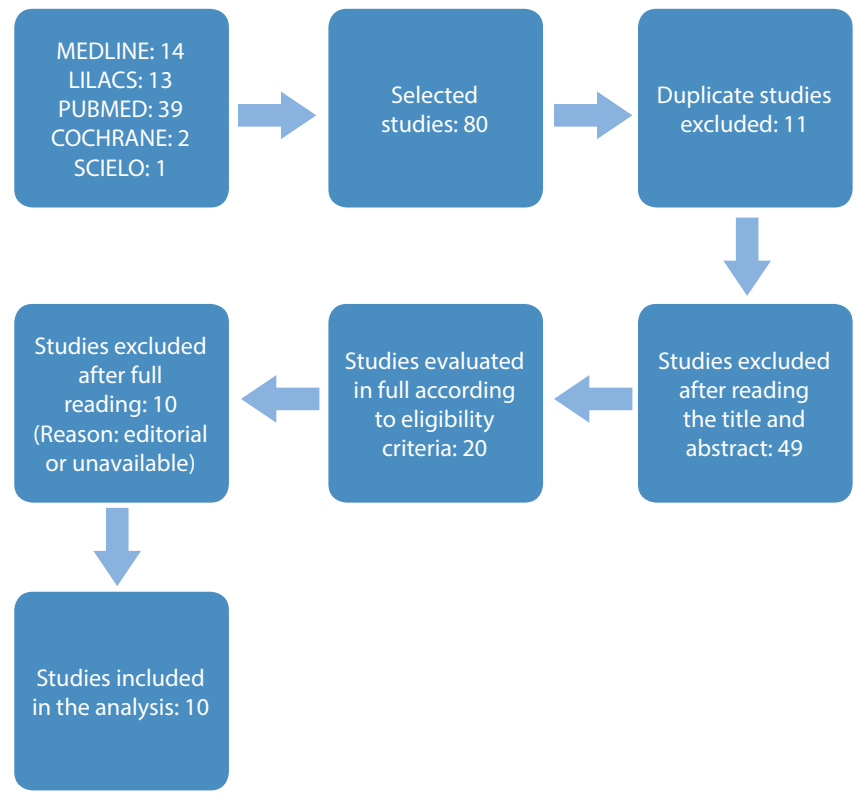

Figure 1 - Flowchart of identification, selection and inclusion of integrative review studies, Belo Horizonte, Minas Gerais, Brazil, 2019

Chart 1 - Characteristics of studies included in the review, Belo Horizonte, Minas Gerais, Brazil, 2019

\begin{tabular}{|c|c|c|c|c|c|}
\hline $\begin{array}{c}\text { Authors/Article } \\
\text { Title }\end{array}$ & $\begin{array}{l}\text { Year/ } \\
\text { Country }\end{array}$ & Design/sample & Interventions & Main Results & $\begin{array}{l}\text { Recommendations/ } \\
\text { Conclusions }\end{array}$ \\
\hline $\begin{array}{l}\text { Christine A.S, } \\
\text { Theresa A.M. } \\
\text { Under pressure: } \\
\text { preventing pressure } \\
\text { ulcers in critically ill } \\
\text { infants }{ }^{(11)}\end{array}$ & $\begin{array}{l}2013 \\
\text { USA }\end{array}$ & $\begin{array}{l}\text { Quasi } \\
\text { Experimental/ } \\
\text { ( } \mathrm{n}=399 \text { children } \\
\text { from } 0 \text { to } 3 \\
\text { months) }\end{array}$ & $\begin{array}{l}\text { To determine if Bundle on } \\
\text { prevention of ulcers by } \\
\text { pressure was associated with } \\
\text { a significant reduction in } \\
\text { ulcers by pressure on children } \\
\text { in Neonatal and Pediatric } \\
\text { Intensive Care Units. Bundle } \\
\text { Components included: to } \\
\text { ensure that patients were kept } \\
\text { in correct surface support to } \\
\text { decrease the pressure of tissue } \\
\text { interface; frequent turning; } \\
\text { management of incontinence; } \\
\text { proper nutrition and education. }\end{array}$ & $\begin{array}{l}\text { The use of the Bundle was } \\
\text { associated with a significant } \\
\text { decrease in the incidence of } \\
\text { ulcers by pressure from } 18.8 \\
\text { to } 6.8 \% \text {. }\end{array}$ & $\begin{array}{l}\text { Pressure ulcers can be } \\
\text { Prevented in the most } \\
\text { vulnerable patients with } \\
\text { the implementation } \\
\text { consistent of } \\
\text { interventions based in } \\
\text { scientific evidence and } \\
\text { support systems to assist } \\
\text { the nurses by changing } \\
\text { practice. }\end{array}$ \\
\hline $\begin{array}{l}\text { Tina L, Carol B. } \\
\text { Randomized, } \\
\text { Controlled Trial } \\
\text { Evaluating a Baby } \\
\text { Wash Product on } \\
\text { Skin Barrier Function } \\
\text { in Healthy, Term } \\
\text { Neonates }{ }^{(12)}\end{array}$ & $\begin{array}{c}2013 \\
\text { England }\end{array}$ & $\begin{array}{l}\text { Randomized } \\
\text { Controlled Study } \\
\text { ( } \mathrm{n}=242 \text { newborn } \\
<1 \text {-month-old) }\end{array}$ & $\begin{array}{l}\text { To examine if a product } \\
\text { formulated for the bath } \\
\text { of newborn has different } \\
\text { outcomes compared to bath } \\
\text { with water alone. }\end{array}$ & $\begin{array}{l}\text { Significant differences } \\
\text { were not found in } \mathrm{pH} \\
\text { measurements and } \\
\text { transepidermal water loss } \\
\text { between the two groups. }\end{array}$ & $\begin{array}{l}\text { The authors suggest the } \\
\text { use of neutral product } \\
\text { or other technically } \\
\text { equivalente cleaners. }\end{array}$ \\
\hline $\begin{array}{l}\text { Visscher M.O, } \\
\text { Taylor T. Neonatal } \\
\text { intensive care } \\
\text { practices and the } \\
\text { influence on skin }_{\text {condition }^{(13)}}\end{array}$ & $\begin{array}{l}2013 \\
\text { USA }\end{array}$ & $\begin{array}{c}\text { Cohort } \\
\text { Retrospective } \\
(\mathrm{n}=130 \text {, being } 97 \\
\text { preterm infants and } \\
33 \text { newborn at term) }\end{array}$ & $\begin{array}{l}\text { To examine the effects of } \\
\text { prematurity and gestation } \\
\text { age (time to adaptation) in } \\
\text { maturation and integrity of } \\
\text { stratum corneum in newborns } \\
\text { Neonatal Intensive Care Units. }\end{array}$ & $\begin{array}{l}\text { The shorter gestational age, } \\
\text { time of contact with the } \\
\text { feces, the use of formulas and } \\
\text { parenteral nutrition influence } \\
\text { the appearance of lesion. }\end{array}$ & $\begin{array}{l}\text { The low exposure to } \\
\text { feces and the longest } \\
\text { time before the first } \\
\text { contact with feces seem } \\
\text { to be protective against } \\
\text { skin damage. }\end{array}$ \\
\hline $\begin{array}{l}\text { Simone V.S, } \\
\text { Roberta C. } \\
\text { Prevention of } \\
\text { newborn skin lesions: } \\
\text { knowledge of the } \\
\text { nursing team } \\
{ }^{(14)}\end{array}$ & $\begin{array}{l}2015 \\
\text { Brazil }\end{array}$ & $\begin{array}{l}\text { Convergent care } \\
\text { Care Research } \\
\text { ( } \mathrm{n}=14 \text { nursing } \\
\text { professionals) }\end{array}$ & $\begin{array}{l}\text { To determine the knowledge } \\
\text { of the nursing teams about } \\
\text { practice and prevention of } \\
\text { skin lesions in newborns } \\
\text { hospitalized in neonatal units. }\end{array}$ & $\begin{array}{l}\text { The results point that } \\
\text { professionals have knowledge of } \\
\text { particularities of the newborn's } \\
\text { skin and recognize the need } \\
\text { for care on thermal regulation, } \\
\text { transepidermal water loss, } \\
\text { hygiene, hydration and handling } \\
\text { in addition to care with invasive } \\
\text { procedures, prevention of } \\
\text { pressure lesions, and care with } \\
\text { venous and arterial punctures } \\
\text { and the use of antiseptics. }\end{array}$ & $\begin{array}{l}\text { Despite the knowledge } \\
\text { of staff in regarding skin } \\
\text { care, it is necessary to } \\
\text { ensure training and team } \\
\text { discussion about the } \\
\text { theme seeking to ensure } \\
\text { the standardization and } \\
\text { improvement of care } \\
\text { provided. }\end{array}$ \\
\hline
\end{tabular}




\begin{tabular}{|c|c|c|c|c|c|}
\hline $\begin{array}{c}\text { Authors/Article } \\
\text { Title }\end{array}$ & $\begin{array}{c}\text { Year/ } \\
\text { Country }\end{array}$ & Design/sample & Interventions & Main Results & $\begin{array}{l}\text { Recommendations/ } \\
\text { Conclusions }\end{array}$ \\
\hline $\begin{array}{l}\text { Simone V.S, } \\
\text { Roberta C. } \\
\text { Treatment of skin } \\
\text { lesions in newborn } \\
\text { children: } \text { meeting } \\
\text { the needs of nursing } \\
\text { staff }{ }^{(1)}\end{array}$ & $\begin{array}{l}2014 \\
\text { Brazil }\end{array}$ & $\begin{array}{l}\text { Convergent care } \\
\text { Care Research } \\
\text { ( } \mathrm{n}=14 \text { nursing } \\
\text { professionals) }\end{array}$ & $\begin{array}{l}\text { To know the Care needed for } \\
\text { the treatment of skin lesions } \\
\text { in NBs admitted to a Neonatal } \\
\text { unit. }\end{array}$ & $\begin{array}{l}\text { The results showed that team } \\
\text { presents difficulties to treat } \\
\text { skin lesions in RN, seen that } \\
\text { the findings revealed the } \\
\text { lack of standardization of the } \\
\text { conducts, which makes it } \\
\text { difficult to take a decision and } \\
\text { to keep assistance to RN. }\end{array}$ & $\begin{array}{l}\text { It is urgent the need } \\
\text { the team know about } \\
\text { the lesion treatment, in } \\
\text { order to provide safer } \\
\text { care to RN and favor the } \\
\text { autonomy of nursing } \\
\text { professional in care } \\
\text { achievement }\end{array}$ \\
\hline $\begin{array}{l}\text { Young DL, } \\
\text { Chakravarthy D, } \\
\text { Drower E, Reyna R. } \\
\text { Skin Care Product } \\
\text { Evaluation in a } \\
\text { Group of Critically } \\
\text { III, Premature } \\
\text { Neonates }^{(15)}\end{array}$ & $\begin{array}{l}2014 \\
\text { USA }\end{array}$ & $\begin{array}{l}\text { Descriptive Study } \\
\qquad(n=29 \text { PTN })\end{array}$ & $\begin{array}{l}\text { To describe the impact of a } \\
\text { specific product containing } \\
\text { a gel or foam base cleaner, } \\
\text { two moisturizers, including } \\
\text { one with silicone and one } \\
\text { protective cream with zinc } \\
\text { oxide on the PTN skin. }\end{array}$ & $\begin{array}{l}\text { Statistics differences were } \\
\text { not found in pain scores }(p= \\
0.132) \text {, perineal erythema ( } p \\
=0.059) \text { or skin condition }(p= \\
0.603 \text { ) of the RN between the } \\
\text { beginning and end of study. }\end{array}$ & $\begin{array}{l}\text { The use of the new } \\
\text { hygiene product has not } \\
\text { improved significantly } \\
\text { total skin condition, } \\
\text { erythema and pain in } \\
\text { newborns of the study. }\end{array}$ \\
\hline $\begin{array}{l}\text { Michelle T.M, } \\
\text { Sarah N.D. } \\
\text { Skin lesions of } \\
\text { newborns in a } \\
\text { neonatal unit: } \\
\text { descriptive study }{ }^{(16)}\end{array}$ & $\begin{array}{l}2013 \\
\text { Brazil }\end{array}$ & $\begin{array}{l}\text { Longitudinal, } \\
\text { observational } \\
\text { study } \\
(n=40 \mathrm{NB})\end{array}$ & $\begin{array}{l}\text { To describe the types of } \\
\text { treatments according to } \\
\text { lesions found in newborns. }\end{array}$ & $\begin{array}{l}\text { A total of } 195 \text { skin lesions } \\
\text { were identified, with average } \\
\text { of five lesions in each RN. The } \\
\text { dermatitis caused by diaper } \\
\text { was the most incident lesion, } \\
\text { and lesion caused by adhesive } \\
\text { labels and nasal lesions were } \\
\text { less expressive. There was } \\
\text { significant statistics for the } \\
\text { antifungal use in dermatitis } \\
\text { caused by diapers and the } \\
\text { use of Essentials Fatty acids } \\
\text { in treatment of lesions by } \\
\text { adhesives labels and nasal } \\
\text { lesions. }\end{array}$ & $\begin{array}{l}\text { The findings point to } \\
\text { the need for preventive } \\
\text { lesion treatment, which } \\
\text { can improve the quality } \\
\text { of life and consequently } \\
\text { growth for newborns. }\end{array}$ \\
\hline \multirow{3}{*}{$\begin{array}{l}\text { Ulrike B.P, Tina L. } \\
\text { Recommendations } \\
\text { from a European } \\
\text { Roundtable } \\
\text { Meeting on Best } \\
\text { Practice Healthy } \\
\text { Infant Skin Care }{ }^{(17)}\end{array}$} & \multirow{3}{*}{$\begin{array}{c}2016 \\
\text { Germany }\end{array}$} & \multirow{3}{*}{ Descriptive Study } & \multirow{3}{*}{$\begin{array}{l}\text { To provide information } \\
\text { relating to care practices with } \\
\text { newborns, such as the bath } \\
\text { and cleaning, the exchange } \\
\text { of diapers and hygiene of this } \\
\text { area and the use of emollients } \\
\text { and other formulated } \\
\text { products. }\end{array}$} & $\begin{array}{l}\text { To use only water or liquid } \\
\text { soaps properly produced. } \\
\text { These can be used during the } \\
\text { bath, without harming the } \\
\text { process of skin maturation. }\end{array}$ & \multirow{3}{*}{$\begin{array}{l}\text { It is expected that health } \\
\text { professionals use these } \\
\text { recommendations based } \\
\text { on evidence to guide } \\
\text { parents to respect of } \\
\text { cleaning practices, bath, } \\
\text { hydration and care with } \\
\text { the diaper area. }\end{array}$} \\
\hline & & & & $\begin{array}{l}\text { The diaper area should be kept } \\
\text { clean and dry and can be gently } \\
\text { cleaned with cotton squares/ } \\
\text { balls and water or using tissues } \\
\text { properly developed. }\end{array}$ & \\
\hline & & & & $\begin{array}{l}\text { Oils appropriately formulated } \\
\text { for babies can be applied to } \\
\text { skin physiological dryness } \\
\text { (transitional) and in small } \\
\text { quantities for the bath. }\end{array}$ & \\
\hline $\begin{array}{l}\text { Lori D.M, Jodi } \\
\text { H.B, Sandra L.S. } \\
\text { Hydrocolloid to } \\
\text { prevent breakdown } \\
\text { of nares in preterm } \\
\text { infants }^{(18)}\end{array}$ & $\begin{array}{l}2015 \\
\text { USA }\end{array}$ & $\begin{array}{c}\text { Cohort } \\
\text { Retrospective } \\
\text { ( } \mathrm{n}=53 \text { NB of very } \\
\text { low weight) }\end{array}$ & $\begin{array}{l}\text { To determine if a hydrocolloid } \\
\text { double barrier dressing } \\
\text { prevents the trauma of the } \\
\text { nostrils and columella in } \\
\text { very low weight NB }(<1500 \mathrm{~g}) \\
\text { receivingheated oxygen and } \\
\text { humidified via high flow nasal } \\
\text { cannula. }\end{array}$ & $\begin{array}{l}\text { There was no significant } \\
\text { differences conditions of } \\
\text { nostril skin between groups or } \\
\text { throughout the time. }\end{array}$ & $\begin{array}{l}\text { No statistics difference } \\
\text { between groups may } \\
\text { have been caused by } \\
\text { the greater surveillance } \\
\text { of NICU nurses facing } \\
\text { the risk of trauma to the } \\
\text { skin. In addition, the } \\
\text { replacement of nasal } \\
\text { CPAP by heated oxygen } \\
\text { and humidified via high } \\
\text { flow nasal cannula, which } \\
\text { makes less pressure on } \\
\text { the tissues of the nostrils, } \\
\text { is becoming more } \\
\text { common. }\end{array}$ \\
\hline
\end{tabular}


Chart 1 (concluded)

\begin{tabular}{|c|c|c|c|c|c|}
\hline $\begin{array}{c}\text { Authors/Article } \\
\text { Title }\end{array}$ & $\begin{array}{l}\text { Year/ } \\
\text { Country }\end{array}$ & Design/sample & Interventions & Main Results & $\begin{array}{l}\text { Recommendations/ } \\
\text { Conclusions }\end{array}$ \\
\hline $\begin{array}{l}\text { Amer M, Diab } \\
\text { N, Soliman M, } \\
\text { Amer A. Neonatal } \\
\text { skin care: what } \\
\text { should we do? A } \\
\text { four-week follow- } \\
\text { up randomized } \\
\text { controlled trial at } \\
\text { Zagazig University } \\
\text { Hospitals }{ }^{(19)}\end{array}$ & $\begin{array}{l}2017 \\
\text { Egypt }\end{array}$ & $\begin{array}{c}\text { Randomized } \\
\text { Controlled Study } \\
\text { (n=70 newborns) }\end{array}$ & $\begin{array}{l}\text { To evaluate effectiveness } \\
\text { of skin care in the neonatal } \\
\text { period, to promote normal skin } \\
\text { development and protection } \\
\text { of skin function great, to avoid } \\
\text { the many different neonatal } \\
\text { cutaneous disturbances that } \\
\text { cause infections of skin. That } \\
\text { is achieved by optimization of } \\
\text { integrity of epidermal barrier, } \\
\text { including the bath and the use } \\
\text { of softeners, preventing and } \\
\text { managing infections and lesions } \\
\text { of the skin, and minimizing } \\
\text { the transepidermal water loss } \\
\text { (TEWL) and heat or absorption } \\
\text { percutaneous toxins. }\end{array}$ & $\begin{array}{l}\text { There were significant } \\
\text { differences between the group } \\
\text { of newborns that received the } \\
\text { conventional skin care without } \\
\text { standardization of products, } \\
\text { and the group that received } \\
\text { care with cleaning products } \\
\text { designed for the baby's skin, } \\
\text { that is, with neutral ph and } \\
\text { gentle. The last one had less } \\
\text { allergic dermatitis. }\end{array}$ & $\begin{array}{l}\text { It is recommended } \\
\text { the use of especially } \\
\text { developed products } \\
\text { for cleaning baby's skin } \\
\text { with neutral pH and very } \\
\text { gentle to prevent irritant } \\
\text { dermatitis and allergic } \\
\text { dermatitis. }\end{array}$ \\
\hline
\end{tabular}

Chart 2 - Scientific Evidence According to Melnyk and Fineout-Overholt for the prevention and care of newborn skin lesions, Belo Horizonte, Minas Gerais, Brazil, 2019

\begin{tabular}{|c|c|}
\hline Recommendations for safe skin care of hospitalized newborn & Level \\
\hline \multicolumn{2}{|l|}{1 - General care in the prevention of skin lesions } \\
\hline Use of superabsorbent disposable diapers with changes every three to four hours or when soiling occurs(14). & 6 \\
\hline The diaper area should be gently wiped with cotton balls or soft wipers and water ${ }^{(17)}$. & 5 \\
\hline $\begin{array}{l}\text { Essential fatty acid (EFA) emollients should be applied immediately after bathing, and fragrant products should be avoided because of the } \\
\text { risk of sensitization and irritation }{ }^{(14)} \text {. }\end{array}$ & 6 \\
\hline Emollients should be applied in a thin layer to avoid occlusive effects and entrapment of emollients between the skin ${ }^{(17)}$. & 5 \\
\hline Use of zinc oxide as ointment or cream for three to five days in cases of perianal hyperemia(19). & 1 \\
\hline \multicolumn{2}{|l|}{2 - Bath and body care products } \\
\hline The premature baby should be washed only with water, two to three times a week, discouraging daily bathing and the use of soaps ${ }^{(14)}$. & 6 \\
\hline \multicolumn{2}{|l|}{3 - Thermoregulation and moisturizing skin } \\
\hline Use of a cotton cap on the newborn's head, reducing heat loss through the cephalic region ${ }^{(14)}$. & 6 \\
\hline Use of occlusive skin cover with polyurethane film to reduce evaporative heat loss ${ }^{(14)}$. & 6 \\
\hline $\begin{array}{l}\text { Use of cribs and incubators, being the humidified incubators more suitable for newborns weighing less than } 1000 \mathrm{~g} \text { and gestational age } \\
\text { below } 30 \text { weeks }^{(14)} \text {. }\end{array}$ & 6 \\
\hline \multicolumn{2}{|l|}{4 - Use of dressings and adhesives } \\
\hline Use of silicone skin dressing, polyurethane film, hydrocolloid or hydrogel dressing ${ }^{(1)}$. & 6 \\
\hline Removal of adhesives should be done carefully, using gauze moistened with saline or mineral oil(14). & 6 \\
\hline \multicolumn{2}{|l|}{5 - Skin antisepsis before invasive procedures } \\
\hline The most commonly used products for skin antisepsis are isopropyl alcohol, aqueous or alcoholic chlorhexidine gluconate $(\mathrm{CHG})^{(14)}$. & 6 \\
\hline $\begin{array}{l}\text { Small amounts of } 0.5 \% \text { alcohol chlorhexidine are recommended. Aqueous chlorhexidine prevents chemical burns and is reco } \\
\text { use in extreme preterm infants }{ }^{(1)} \text {. }\end{array}$ & 6 \\
\hline
\end{tabular}

\section{RESULTS}

The final sample consisted of ten articles, among which the oldest was published in 2013 and the most recent in 2017. One (10\%) was published in 2017 , one (10\%) in 2016 , two (20\%) in 2015, two (20\%) in 2014 and four (40\%) in 2013. Three (30\%) studies were published in Portuguese and seven (50\%) in English in international and national journals. The authors of four (40\%) studies were nurses or nursing students, four (40\%) were doctors or medical students, and two (20\%) were other professionals.

The most frequent design was the quantitative descriptive method, with five (50\%) studies, followed by randomized controlled trials and cohort with two (20\%) studies in each of these and one quasi-experimental study. Thus, five studies (50\%) 
presented evidence level 6 (weak), two (20\%) studies evidence level 2 (strong), one (10\%) presented evidence level 3 (moderate) and two (20\%) had evidence level 4 (moderate).

\section{DISCUSSION}

The complexity of skin care in neonatology requires wellprepared professionals to work on lesion prevention and skin care of the newborn. Thus, the findings allowed a synthesis of the main recommendations available in the literature.

With regard to handling the newborn, a study suggests that it is performed delicately combined with adequate antisepsis of the devices in use. These practices are central for the prevention of skin lesion and, consequently, offer safer care to patients ${ }^{(14)}$.

The first care to be performed after the baby's birth, in order to avoid temperature fluctuations, concerns thermoregulation and humidification $^{(14)}$. Therefore, health professionals should use strategies to avoid thermal imbalance and adopt the use of cotton hood on the newborn's head, reducing heat loss through the cephalic region and using occlusive coverage on the skin with polyurethane film to decrease evaporative heat loss. Other resources used are heated cribs and incubators, as they contribute to the maintenance of a neutral thermal environment for the preterm infants and help to reduce thermal instability and evaporative loss ${ }^{(20)}$.

Another important aspect regarding to humidification is the capacity of hydration of the vernix caseosa, since premature newborns have a more vulnerable skin due to the lack of this protection and, especially, the stratum corneum in the epidermis ${ }^{(21)}$. Thus, the humidification of incubators causes better thermoregulation, less transepidermal water loss and fluid and electrolyte balance so important for the care of the baby ${ }^{(22)}$.

Bathing is another action that requires professional attention, especially preterm newborns, culminating in hypothermia, imbalance of vital signs, respiratory distress and high oxygen consumption $^{(23-24)}$. Therefore, for a bath to be performed properly, the face and head must be prioritized before the body ${ }^{(25)}$.

At birth, the newborn's skin has a neutral pH and becomes physiologically acidic ( $\mathrm{pH}<5.5)$ within a few days. Daily bathing and soap use can affect the maturation of the acid mantle and raise the skin's $\mathrm{pH}$, which may cause irritation and dryness. Thus, according to the recommendations of a study conducted in the Neonatal Unit of a hospital in Southern Brazil, daily bathing and the use of soaps should be discouraged, cleaning with water only and two to three times a week ${ }^{(14)}$. However, according to a publication by pediatric skin care specialists, the use of mild and appropriately formulated liquid soaps for newborns is well tolerated as these cleansers do not alter the natural process of skin maturation in neonates. In addition, these compounds have neutral or slightly acidic $\mathrm{pH}$, a characteristic emphasized in NB skin care recommendations ${ }^{(17)}$.

The term "clinically tested", which appears in many products aimed at the neonatal population, covers a range of tests and does not provide precise details about the rigor of these investigations and the quality of evidence from clinical trials ${ }^{(12)}$. Therefore, nursing professionals play a key role in educating parents about the proper procedures and the most appropriate skin care products for newborns.
Another recommended action is the use of essential fatty acidbased emollient oils (EFA) to protect the newborn's skin. These are emulsions that restore the elasticity and homeostasis of the skin and prevent the loss of transepidermal water, contributing to the maintenance of the epidermal barrier, since they favor the hydration of the newborn's skin. Thus, it is recommended to apply it immediately after the bath, with the skin still moist ${ }^{(14)}$. The use of emollients containing perfumes should be avoided because of the risk of causing sensitization and irritation ${ }^{(14,26-27)}$.

Regarding skin lesions in the perineal area, the evaluation of diaper change and the use of zinc oxide ointments ${ }^{(28)}$ are measures used to prevent diaper rash. Perianal dermatitis is a common problem in newborn patients due to diaper occlusion of the skin as a result of skin and urine contact. For prevention, strategies such as proper hygiene, constant skin evaluation, use of diapers with high absorption power and changing every three to four hours or in case of soiling, and cleaning the perianal region with warm water and cotton are essential to ensure the integrity of the skin. In this case, the use of emollients is indicated because it minimizes the risk of dermatitis, besides preventing dryness and cracking ${ }^{(14,26)}$.

A study conducted at the NICU (Neonatal Intensive Care Unit) of a university hospital in Londrina (PR) with 40 newborns diagnosed 195 lesions over a period of two months. Data revealed that the most incident lesion was diaper dermatitis, followed by hematoma and ecchymosis and adhesive lesion. For skin repair, the most used product in this study was the EFA, used in 52 lesions, which corresponds to more than a quarter of the total lesions found, reinforcing the use of this product for NB skin care ${ }^{(16)}$.

Many procedures are performed in a NICU in order to preserve the newborn's life and reduce the length of hospital stay. Therefore, many technologies are used by nurses in their assistance to these patients, such as: endotracheal tubes, catheters and nasal prongs, intravenous infusion devices and feeding catheter ${ }^{(14)}$. However, the presence of these devices, allied to the instability conditions of the newborn, may lead to a predisposition to the occurrence of skin lesions and, consequently, to infections in newborns ${ }^{(29)}$.

Other equipment used in infant health promotion interventions is CPAP (Continuous Positive Airway Pressure), which is responsible for assisting in the treatment of problems related to pulmonary immaturity of PTN, but its use is not free from adverse skin events ${ }^{(1)}$. However, one study reveals that the high-flow nasal oxygen catheter may be less harmful when compared to nasal CPAP ${ }^{(18)}$, but the evidence is still weak. Thus, it is suggested that studies on this theme be done in order to seek the prevention of skin lesions in preterm newborns on oxygen therapy ${ }^{(21)}$.

Among NB admitted to the NICU, PTN have a great predisposition to develop pressure lesion, due to numerous interventions, mobility restriction, immature epidermis and sometimes inadequate nutrition. In addition, the use of oxygen catheters, mechanical ventilation and venous devices are identified as causing pressure damage ${ }^{(14)}$. Thus, it is recommended to use special mattresses, change of position with standardized frequency and use of protectors under the devices to prevent pressure damage in newborns ${ }^{(23)}$.

Another precaution to be considered is sticking the devices, as they can easily cause lesions, especially when removed. Thus, 
in addition to analyzing the compatibility of the product with the skin properties of the newborn, less harmful adhesives, such as those of hydrophilic gel, which have a lower feature to adhere to babies' skin should be used. However, nurses in clinical practice opt for more efficient adhesives, which are generally more aggressive to the epidermis ${ }^{(30)}$.

As for dressings, the Association of Women's Health, Obstetric and Neonatal Nurses (AWHONN) recommends the use of these dressings based on silicone, polyurethane film, hydrocolloid or hydrogel, in order to protect the skin from pressure from the use of devices and prevent lesions by adhesive removal(14). Thus, in addition to considering as a requirement of choice the easy fixation and removal of this device, the selected product should provide a favorable environment for healing, while keeping a moist area ${ }^{(1)}$.

In addition, antisepsis and skin cleansing of NB prior to performing any invasive procedure are of utmost importance to prevent infections. Thus, the use of Chlorhexidine Gluconate is indicated, which can be used in alcoholic or aqueous form, eliminating the use of chemicals based on alcohol and iodine, as these can cause irritation, intoxication and burns on the skin of babies. However, in order to avoid chemical damage to the NB's epidermis, it is recommended to use $0.5 \%$ alcoholic chlorhexidine, which should be removed immediately after the procedure by cleaning the area with sterile distilled water ${ }^{(1)}$. Another study points out that the use of $0.5 \%$ aqueous chlorhexidine while handling PTN's skin, specifically, seems to be associated with a higher mortality rate in this population, and advises the use of $0.015 \%$ chlorhexidine ${ }^{(31)}$. However, there is a lack of studies with strong levels of evidence that investigate the implications of these recommendations in the preterm individual, since skin maturity and physiology are directly correlated with gestational age and time to adapt to the extrauterine environment ${ }^{(21)}$.

Through the synthesis of the studies, the findings are still insufficient to substantiate a safe practice in relation to NB skin care. There are still some gaps in scientific knowledge regarding the scales of risk assessment of lesion to the newborn, as well as strategies for associating predisposing factors to individualized and systematized care of prevention actions. It is essential that professionals seek to expand studies with methodological rigor so that decisions taken are based on high levels of scientific evidence, such as experimental studies, aimed at promoting patient safety and scientificity of care.

\section{Study Limitations}

It is worth mentioning as a limitation, the lack of studies with strong levels of evidence about safe skin care of the newborn, so that there is a standardization of care, enabling the improvement of the practice of the multidisciplinary team.

\section{Contributions to nursing, health or public policy}

The relevance of this study comes from the training of health professionals in the promotion of qualified care to newborns admitted to a NICU regarding the skin care of these patients. This study can be useful to support the practice based on scientific evidence and arouse the interest of professionals to deepen their knowledge on this subject, and contribute to a more effective and safe care for the newborn.

\section{FINAL CONSIDERATIONS}

Safe and proper care of the newborn's skin is essential to keep the protective barrier function against external agents. Thus, the review brought important findings related to lesion prevention and skin care of neonates admitted to a NICU. It is possible to promote newborn skin integrity by bathing two to three times a week using only water or neutral liquid soaps; gently sanitize diaper areas with cotton and water; use appropriately formulated emollients; pay attention to the correct procedures for thermoregulation and humidification of the baby's skin; prevent pressure lesions and fixation of the devices and dressings with adhesives that are easy to fix and remove.

Although the prevention and skin care practices presented in the articles have moderate to low level of evidence, they need to be incorporated into clinical practice for the safety of newborns. Moreover, it is important to encourage the development of experimental studies to increase the reliability of available scientific evidence.

\section{REFERENCES}

1. Santos SV, Costa R. Treatment of skin lesions in newborn children: meeting the needs of nursing staff. Rev Esc Enferm USP. 2014;48(6):98592. doi: 10.1590/S0080-623420140000700004

2. Gaíva MAM, Rondon JN, Jesus LN. Segurança do paciente em unidade de terapia intensiva neonatal: percepção da equipe de enfermagem. Rev Soc Bras Enferm Ped [Internet]. 2017 [cited 2019 Oct 29];17:14-20. Available from: https://sobep.org.br/revista/images/stories/pdfrevista/vol17-n1/vol_17_n_1-artigo_original_2.pdf

3. Sousa FCP, Montenegro LC, Goveia VR, Corrêa AR, Rocha PK, Manzo BF. A participação da família na segurança do paciente em unidades neonatais na perspectiva do enfermeiro. Texto Contexto Enferm. 2017;26(3):e1180016. doi: 10.1590/0104-07072017001180016

4. Rolim KMC, Farias CPX, Marques LC, Magalhães FJ, Gurgel EPP, Caetano JA. Atuação da enfermeira na prevenção de lesão de pele de recémnascido. Rev Enf UERJ [Internet]. 2009 [cited 2019 Apr 30];17(4):544-49. Available from: www.facenf.uerf.br/v17n4a16.pdf

5. World Health Organization (WHO). The Launch of the World Alliance for Patient Safety: “First do no harm” [Internet]. WHO; 2004[cited 2019 Apr 30]. Available from: https://www.who.int/patientsafety/worldalliance/en/

6. Whittemore R, Knafl K. The integrative review: updated methodology. J Adv Nurs. 2005;52(5):546-53. doi: 10.1111/j.1365-2648.2005.03621.x. 
7. Mendes KDS, Silveira RCCP, Galvão CM. Revisão integrativa: método de pesquisa para a incorporação de evidências na saúde e na enfermagem. Texto Contexto Enferm. 2008;17(4):758-64. doi: 10.1590/S0104-07072008000400018

8. McDonald S, Crumley E, Eisinga A, Villanueva E. Search strategies to identify reports of randomized trials in Medline: protocol for a Cochrane review. Oxford: The Cochrane Library; 2006.

9. Atallah NA, Castro AA. Revisão sistemática da literatura e metanálise: a melhor forma de evidência para a tomada de decisão em saúde e a maneira mais rápida de atualização terapêutica. São Paulo: Lemos-Editorial; 1998. Evidências para melhores decisões clínicas; p. 20-8.

10. Melnyk BM, Fineout-Overholt E. Evidence-based practice in nursing \& healthcare: a guide to best practice. Philadelphia: Wolters Kluwer, Lippincott Williams \& Wilkins; 2011. p.3-24. Philadelphia: Lippincot; 2005. 3-24 p.

11. Schindler CA, Mikhailov TA, Cashin SE, Malin S, Christensen M, Winters JM. Under pressure: Preventing pressure ulcers in critically ill infants. J Spec Pediatr Nurs. 2013;18(4):329-41. doi: 10.1111/jspn.12043.

12. Tina L, Bedwell C, Roberts SA, Hart A, Turner MA, Carter LA, Cork M. Randomized, controlled trial evaluating a baby wash product on skin barrier function in healthy, term neonates. J Obstet Gynecol Neonatal Nurs. 2013;42(2):203-14. doi: 10.1111/1552-6909.12015

13. Visscher MO, Taylor T, Narendran V. Neonatal intensive care practices and the influence on skin condition. J Eur Acad Dermatol Venereol. 2013;27(4):486-93. doi: 10.1111/j.1468-3083.2012.04470.x

14. Santos SV, Costa R. Prevention of newborn skin lesions: knowledge of the nursing team. Texto Contexto Enferm. 2015;24(3):731-9. doi: 10.1590/0104-07072015011230014

15. Young DL, Chakravarthy D, Drover E, Reyna R. Skin care product evaluation in a group of critically ill, premature neonates: a descriptive study. J Wound Ostomy Continence Nurs. 2014;41(6):519-27. doi: 10.1097/WON.0000000000000083

16. Migoto TM, Souza SNDH, Rossetto EG. Skin lesions of newborns in a neonatal unit: observational study. Online Braz J Nurs. 2013;12(2):37792. doi: 10.5935/1676-4285.20134042

17. Blume-Peytavi U, Lavender T, Jenerowicz D, Ryumina I, Stalder JF, Torrelo A, et al. Recommendations from a European Roundtable Meeting on Best Practice Healthy Infant Skin Care. Pediatr Dermatol. 2016;33(3):311-21. doi: 10.1111/pde.12819

18. Morris LD, Behr JH, Smith SL. Hydrocolloid to Prevent Breakdown of Nares in Preterm Infants. MCN Am J Matern Child Nurs. 2015;40(1):3943. doi: $10.1097 /$ NMC.0000000000000099

19. Amer M, Diab N, Soliman M, Amer A. Neonatal skin care: what should we do? A four-week follow-up randomized controlled trial at Zagazig University Hospitals. Int J Dermatol. 2017;56 (11):1198-203. doi: 10.1111/ijd.13735

20. Ministério da Saúde (BR). Secretaria de Atenção à Saúde, Departamento de Ações Programáticas e Estratégicas. Atenção à saúde do recémnascido: guia para os profissionais de saúde - Cuidados com o recém-nascido pré-termo. Brasília (DF): MS; 2011.

21. Aredes NDA, Santos RCA, Fonseca LMM. Skin care of premature newborns: integrative review. Rev Eletr Enf. 2017;19:a59. doi: 10.5216/ree.v19.43331

22. Sinclair L, Crisp J, Sinn J. Variability in incubator humidity practices in the management of preterm infants. J Paediatr Child Health. 2009;45(9):535-40.doi: 10.1111/j.1440-1754.2009.01555.x

23. Ness MJ, Davis DMR, Carey WA. Neonatal skin care: a concise review. Int J Dermatol. 2013;52(1):14-22. doi: 10.1111/j.1365-4632.2012.05687.x

24. Jackson A. Time to review newborn skincare. Infant[Internet]. 2008[cited 2019 Apr 30];4(5):168-71. Available from: http://www.infantjournal. co.uk/pdf/inf_023_rwn.pdf

25. Beltrão MMN, Javorski M, (Orgs.). Cuidados com crianças e adolescentes. Recife (PE): Editora Universitária; 2007.

26. Fernandes JD, Machado MCR, Oliveira ZNP. Prevenção e cuidados com a pele da criança e do recém-nascido. An Bras Dermatol. 2011;86(1):102-10. Available from: 10.1590/S0365-05962011000100014

27. Oliveira ZNP, organizador. Dermatologia pediátrica. Barueri (SP): Manole; 2009.

28. Javorski M, Leal LP, Vasconcelos SC, Souza FTC, Petrício JLCS, Mendes JA. Problemas de pele e mucosas: identificação dos fatores relacionados e características definidoras. Rev Nurs [Internet]. 2006[cited 2019 Apr 30];92:638-42. Available from: https://pesquisa.bvsalud. org/portal/resource/pt/lil-522508

29. Rolim KMC, Barbosa RMA, Medeiros RMG, Leite ML, Gurgel EPP. Permanência da membrana semipermeável na pele do recém-nascido: um cuidado diferenciado. Rev Rene [Internet]. 2010[cited 2019 Apr 30];11(1):144-51. Available from: http://periodicos.ufc.br/rene/article/ view/4493

30. O'Neil A, Schumacher B. Application of a Pectin Barrier for Medical Adhesive Skin Injury (Epidermal Stripping) in a Premature Infant. J Wound, Ostomy Cont Nurs. 2014;41(3):219-21. doi: 10.1097/WON.0000000000000029.

31. Bredemeyer SL, Reid S, Evans N, Gibbons E. Randomised controlled trial of two strengths of topical Aqueous chlorhexidine for prevention of nosocomial infection in neonates born before 29 weeks. J Paediatr Child Health. 2011;47(Supl.-s1):64-5. doi: 10.1111/j.1440-1754.2011.02047.x 